Creative commons User License: CC BY-NC-ND

Abstracted by: EBSCOhost, Electronic Journals Service (EJS),

Google Scholar, Directory of Open Access Journals (DOAJ),

Journal Seek, Scientific Commons,

Food and Agricultural Organization (FAO), CABI and Scopus
Journal of Agricultural Extension

Vol. 21 (3) October, 2017

ISSN(e): 24086851; ISSN(Print); $1119944 X$

http://journal.aesonnigeria.org

http://www.ajol.info/index.php/jae

Email: editorinchief@aesonnigeria.org

\title{
The Economic Effect of Insurgency on Smoked Fish Sellers in Maiduguri Metropolis of Borno State Nigeria
}

https://dx.doi.org/10.4314/jae.v21i3.4

\section{Bello, M. M.}

Department of Fisheries, Faculty of Agriculture, University of Maiduguri, Maiduguri, Borno

State Email:mmbello@unimaid.edu.ng, Phone:+234-8035663565

Sani, $\mathbf{H}$.

Department of Fisheries, Faculty of Agriculture, University of Maiduguri, Maiduguri, Borno

State Email: hamidusani1983.hs@gmail.com, Phone:+234-8034568876

\section{Bukar, A.}

Department of General Agriculture, Mohammed Lawan College of Agriculture, Borno State

Email:chibun_20@hlyahoo.com, Phone: +234-8034334393

Rabiu, M. M.

Department of Agricultural Extension Services, University of Maiduguri, Borno State Email: haamuza@gmail.com, Phone: +234-8020663339

\section{Abstract}

The research examined the economic effect of insurgency on smoked fish sellers in Baga fish marketing Maiduguri metropolis of BornoState, Nigeria. Primary data were collected using questionnaires. A total of 60 respondents were randomly selected for the study. Descriptive statistics and gross margin was used to analyse data generated. The result reveales that $91.7 \%$ of the respondents were male, $83.3 \%$ married, 53.3\% were between $41-60$ years, $41.7 \%$ constitute family size of between 1-5, 33.3\% of the respondent had moderate educational level while $90 \%$ had trading as their main occupation. The previous and present gross margin values for small, medium and large carton of smoked fish were (N1, 402.00, N1, 962.20, and N4, 455.30) and (N1, 733.80, N13, 893.00 and N66, 488.70) respectively. The problems mostly encountered were poor storage facilities, pests and disease, lower market price by the buyers due to its perishable nature and lack of access to capital with 21.9\%, 31.4\% $22.5 \%$ and $24.3 \%$ respectively. The insurgency attack has negative effect on the economic activities of smoke fish sellers. Local dried fish marketers should be organized into cooperative groups by extension agents and government should provide adequate infrastructural facilities such as modern storage facilities, good road network etc.

Keywords: Fish seller, Insurgency, Baga market 
Creative commons User License: CC BY-NC-ND

Abstracted by: EBSCOhost, Electronic Journals Service (EJS), Google Scholar, Directory of Open Access Journals (DOAJ), Journal Seek, Scientific Commons,

Food and Agricultural Organization (FAO), CABI and Scopus
Journal of Agricultural Extension

Vol. 21 (3) October, 2017

ISSN(e): 24086851; ISSN(Print); 1119944X

http://journal.aesonnigeria.org

http://www.ajol.info/index.php/jae

Email: editorinchief@aesonnigeria.org

\section{Introduction}

Fish constitutes a very important component of diet for many people and often provide much needed nutrient for a healthy living (Adeleke and Afolabi, 2012; Olaoye, 2010). Fish serve as a principal source of dietary protein which is very inexpensive in relation to other protein food (Folorunso et al., 2006; Olaoye, Adekoya, Ezeri, Omonyimi and Ayansanwo, 2007). The fish muscle contain four basic nutrient in varying proportions; water $70-80 \%$, protein $16-25 \%$, lipid $1-5 \%$ and vitamins (Ojo and Fagbenro, 2004; Amusan and Okorie, 2002) which makes it less tough and more digestible compared to beef, chicken and mutton (Oloruntoba and Adegbite, 2006; Kainga and Adeyemo, 2012). However, fish is an extremely perishable food commodity than cattle, sheep and poultry, it gets spoil very quickly after capture (Adeosun and Adebukola, 2012; Omoregie et al., 2001), hence it is subject to post-harvest losses ranging from bacterial and autolytic spoilage to other factors (Fasakin and Aberejo, 2002). These causes fish to lose its organoleptic qualities and generally unacceptable for human consumption as the quality diminishes (Ashamo and Ajayi, 2003; Folorunso et al., 2006). Fish has been preserved into different forms due to its perishability, such as smoked, canned fish, fish cake, fish meal, fish burger etc. (Afolabi, 2008; Aderolu and Akpabio, 2009). Fish is a major source of food in West Africa and beyond (Akinwumi, 2011; Okorie, 2003). In view of its importance as a source of food, the demand for fish has been on the increase (Sabry, 1990; Ogadep, 2005). In the quest for meeting the needs of fish consumers across the west African sub-region, fish farmers and or sellers began to develop various means of storing the fish in order to preserve it for a longer period and moreover, to package it and get it across to other places where there is scarcity (Ofuya, 2003; Azam, Ali, Asaduzzaman, Basher and Hossain, 2004). The major challenge faced by fish marketers is that fish are perishable and easily infested by pests (Johnson and Esser, 2005; Tunaz and Uygun, 2004). It is in the light of this that most fish farmers developed the smoking method of fish preservation. However, the raging boko haram insurgency in the north east hit the regions fishing industry, causing shortages and driving up prices (National Emergency Management Agency (NEMA), 2015). Maiduguri has been particularly affected as the authorities in neighbouring Niger have detained huge consignments of smoked fish on security ground (National Commission for Refuge Management (NCRM), 2015). More than 200 vehicles loaded with fish had been detained in Diffa, Niger republic, for several months, which lead to scarcity of fish in Maiduguri (Faith and Aminu, 2015). The fish supply to Maiduguri has been disrupted and price have soared (Faith and Aminu, 2015).

Marketing channel is simply the path of a commodity from its raw form to the finished product or the path of a product as it moves from the producers to the final consumers (Olukosi et. al., 2005). In other words, it is the sequence of intermediaries or middle, and the marketers through which goods passes from producers to consumers (Olukosi et al., 2005). Marketing channels are important in evaluating marketing system because they indicate how the various market participants are organized to accomplish the movement of a product from the producer to the final consumers. According to Gona et al. (2004) the number of middle men in the indigenous marketing system for the agricultural product has been a subject of considerable debate in government and academic circle. The concern has to do with 
Creative commons User License: CC BY-NC-ND

Abstracted by: EBSCOhost, Electronic Journals Service (EJS),

Google Scholar, Directory of Open Access Journals (DOAJ),

Journal Seek, Scientific Commons,

Food and Agricultural Organization (FAO), CABI and Scopus
Journal of Agricultural Extension

Vol. 21 (3) October, 2017

ISSN(e): 24086851; ISSN(Print); $1119944 X$

http://journal.aesonnigeria.org

http://www.ajol.info/index.php/jae

Email: editorinchief@aesonnigeria.org

the existence of so many middlemen in the distribution chain of food products (Imoudu and Afolabi, 2002). The shorter the marketing channel, the more efficient the market, and the higher the net profit on sales of products (Madugu and Edward, 2011). Fish marketing does not usually involve the fishermen and consumers only but there are other players in the fish distribution channels especially middlemen (Lawal and Idega, 2004). Consequently, prices of fish change as it passes through these middlemen such that by the time it reaches consumers, it becomes expensive. Fish sellers have suffered so much financial setback as a result of the Boko haram insurgency (Abubakar, 2015; Nossifer, 2015).

\section{Purpose of the study}

The overall purpose of the study was to examine the impact of insurgency on economic activities of smoked fish in Baga Park Fish Market Maiduguri, Borno State, Nigeria. Specifically, the study sought to:

i. determine the socio economics characteristics of smoked fish marketers;

ii. examine cost and return of smoked fish marketing before and after insurgency ;

iii. determine marketing chain and margin of smoked fish marketing;

iv. identify marketing constraint to smoked fish.

\section{Methodology}

The study was carried out in Borno State, North eastern zone of Nigeria. Its capital is Maiduguri (also known as 'Yerwa'), which lies within latitude $10^{\circ} \mathrm{N}$ and $14^{\circ} \mathrm{N}$ and longitude $11^{\circ} 3^{1} \mathrm{E}$ and $14^{\circ} 4^{1} \mathrm{E}$. Borno State which has an area of $61,435 \mathrm{sqkm}$ is the largest state in the Federation in terms of land mass. The State occupies the greatest part of the Chad Basin and shares borders with the Republics of Niger to the North, Chad to the North-East and Cameron to the East (Ministry of Land and Survey Maiduguri, 2008). Maiduguri, shares boundaries with Konduga Local Government Area to the North and Northwest and Jere Local Government Area to the South. The climate of the study area is characterized by dry and hot season, with mean annual temperature of $25^{\circ} \mathrm{C}$. The hottest months are March and April with maximum temperature of $37-40^{\circ} \mathrm{C}$, while the coldest months are December and January and with rainfall of about $500-700 \mathrm{~mm}$ per annum (Nigeria Meteorological Agency, 2014). The majority of the inhabitants are farmers, fishermen, traders or civil servants (BOSADP, 2007).

The data collection was from both primary and secondary sources. The primary source was mainly interview, with the aid of questionnaire. Sixty questionnaires were distributed randomly to the respondents. Secondary sources, are Journals, textbooks, book of abstracts, conference proceedings, Internet etc. Stratified random sampling was used to divide the marketers into two that is wholesaler and retailer. Thirty questionnaires out of the sixty were distributed to the wholesalers and the remaining 30 questionnaire were also distributed to the retailers. Descriptive statistics and gross margin was used as analytical tools in the research. 
Creative commons User License: CC BY-NC-ND

Abstracted by: EBSCOhost, Electronic Journals Service (EJS), Google Scholar, Directory of Open Access Journals (DOAJ), Journal Seek, Scientific Commons,

Food and Agricultural Organization (FAO), CABI and Scopus

\author{
Journal of Agricultural Extension \\ Vol. 21 (3) October, 2017 \\ ISSN(e): 24086851; ISSN(Print); 1119944X \\ http://journal.aesonnigeria.org \\ http://www.ajol.info/index.php/jae \\ Email: editorinchief@aesonnigeria.org
}

\section{Results and Discussion}

Table 1 reveales the socio-economic characteristics of the respondent, $91.7 \%$ of the respondents were male, while $8.3 \%$ were female. This indicates that fish marketing was dominated by male. This result is in line with study carried out by Orobiyi (2007) who observed that all fish marketers in Maiduguri are male. This could be attributed to high energy required in performing the marketing operations and cultural background. The marital indicates that, $83.3 \%$ of the respondents were married, $6.7 \%$ of respondent were single while $6.7 \%$ represent widow while $3.3 \%$ of the

respondents were divorced. This reveals that the majority of respondents were married, the involvement of married people as reported by Kwaghe, Gaya, and Patrick (2008) means that the trade is remunerative to cater for family responsibilities.

The respondents with $53.3 \%$ are within the age of $41-60$ years, $25 \%$ fall within the age bracket of 21-40 years while $21.7 \%$ were within the ages of 60 years and above. The mean age of the fish trader is 40.5 and are actively involved in fish marketing. Akinwusi (1995), reported that marketing activities involve making the product available to the consumer in the form, place, time and at price the consumers are willing to buy, as such marketers below the age of 30 are few.

\section{Table 1: Socio-economic characteristics}

\begin{tabular}{ll}
\hline Characteristics & Percentage $(\%)(\mathbf{n}=\mathbf{6 0})$ \\
\hline Sex & \\
Male & 91.7 \\
Female & 8.3 \\
Marital Status & 6.7 \\
Single & 83.3 \\
Married & 3.3 \\
Divorcee & 6.7 \\
Widow & 25.0 \\
Age (years) & 53.3 \\
$21-40$ & 21.7 \\
$41-60$ & 33.3 \\
Above 60 & 28.3 \\
Educational level & 3.3 \\
Tertiary & 30.0 \\
Secondary & 5.0 \\
Primary & \\
Quranic & 26.7 \\
Informal & 41.7 \\
Household Size & 15.0 \\
$0-1$ & 16.7 \\
$1-5$ & 90.0 \\
6 -10 & 5.0 \\
M-15 & 1.7 \\
Main occupation & 3.3 \\
Civil sed Fish Trading & \\
Crop Farming &
\end{tabular}

Source: Field Survey, 2016

The educational level, shows that $33.3 \%$ of the respondents had tertiary level of education, $30 \%$ had informal education, and $28.3 \%$ had secondary education. However, 5\% had Quranic education while 3.3\% had primary education. As 
Creative commons User License: CC BY-NC-ND

Abstracted by: EBSCOhost, Electronic Journals Service (EJS),

Google Scholar, Directory of Open Access Journals (DOAJ),

Journal Seek, Scientific Commons,

Food and Agricultural Organization (FAO), CABI and Scopus
Journal of Agricultural Extension

Vol. 21 (3) October, 2017

ISSN(e): 24086851; ISSN(Print); $1119944 X$

http://journal.aesonnigeria.org

http://www.ajol.info/index.php/jae

Email: editorinchief@aesonnigeria.org

observed by Ahmed (2008), education provides marketers with knowledge and skills that enhance marketing activities thereby ensuring efficiency in market performance as well as improving the standard of living of the marketer.

The household sizes of the respondents, $41.7 \%$ of the respondent had $1-5$ as family size, $26.7 \%$ were single and $16.7 \%$ of the respondent had greater than 11 in their house hold while $15 \%$ had 6-10 family size (household). The family size, indicates that the fish marketers would not have remained in the business, if it is not profitable to meet their family need. This is in agreement with findings of Kwaghe, Gaya, and Patrick (2008) who opined that profitability of business is one driving motivational factors that attract people to any particular venture.

The occupational status of the respondents showed that $90 \%$ of the respondents were traders, $5 \%$ were civil servant. However, $3.3 \%$ were artisans and $1.7 \%$ of the respondents engaged in farming activities.

Table 2, reveales the problems faced by the respondents which includes, poor storage facilities, pests and diseases, low bargaining price and poor access to capital.

Table 2: Problems encountered by the respondents

\begin{tabular}{ll}
\hline $\begin{array}{l}\text { Problem } \\
\text { encountered }\end{array}$ & $\begin{array}{l}\text { Percentage } \\
(\mathbf{n}=60)\end{array}$ \\
\hline Poor storage facilities & 21.8 \\
Pest and Disease & 31.4 \\
Low bargaining price & 22.5 \\
Lack of access to & 24.3 \\
capital & \\
Total & $\mathbf{1 0 0 . 0}$ \\
\hline
\end{tabular}

Source: Field Survey, 2016

The study reveales that $31.4 \%$ of the respondents indicates that pests and diseases ultimately affect their fish invariably profit. Also, $24.3 \%$ complain of lack of access to capital to expand their small scale business. Furthermore, low bargaining price and poor storage facilities also constitute $22.5 \%$ and $21.9 \%$ of the problems, respectively. This work agreed with the findings of Abah, Zaknayiba and Simon (2013) that, due to lack of good storage facilities, there is limit to which a seller or consumer will keep unsold products. This is especially the case when fish in its fresh form. In this regards, retailers are likely to obtain higher profits because of the risk they bear as sales are gradual and can take longer periods. Secondly, wholesalers usually travel long distances to procure products and therefore bear the cost of transport and loading. These constitute part of their variable cost thereby reducing profit margin. Thirdly, volume of sales, by wholesalers it higher and thus buyers, mostly retailers enjoy the benefit of scale economics as a result.

The gross margin of small, medium and large carton of smoked fish before insurgency was represented in Table 3. 
Creative commons User License: CC BY-NC-ND

Abstracted by: EBSCOhost, Electronic Journals Service (EJS),

Google Scholar, Directory of Open Access Journals (DOAJ),

Journal Seek, Scientific Commons,

Food and Agricultural Organization (FAO), CABI and Scopus
Journal of Agricultural Extension

Vol. 21 (3) October, 2017

ISSN(e): 24086851; ISSN(Print); 1119944X

http://journal.aesonnigeria.org

http://www.ajol.info/index.php/jae

Email: editorinchief@aesonnigeria.org

Table 3: Gross margin of small, medium and large cartons of smoked fish before insurgency

\begin{tabular}{llll}
\hline \multicolumn{4}{c}{ Cost before insurgency(N) } \\
\hline & Small & Medium & Large \\
Gross revenue & 12,667 & 34,333 & 68,733 \\
Purchasing price & 11,265 & 32,371 & 64,333 \\
Rent & 121 & 250 & 900 \\
Transport & 23.75 & 47.5 & 61.25 \\
Loading /offloading & 95.23 & 100.31 & 123.4 \\
Tax & 25.02 & 40.01 & 60.01 \\
Total variable & 1,126 & 33,771 & 65,478 \\
Gross margin & 1,402 & 1962.2 & 4,455 \\
& & &
\end{tabular}

Source: Field Survey, 2016

Table 3, reveales the gross margin for previous period as 1,402 for small, 1962.2 for medium and 4455.3 for large. This shows that, the profit improved even after insurgency though the total variable cost was higher after the insurgency. The gross margin of small, medium and large cartons of smoked fish after insurgency was represented in Table 4.

Table 4: Gross margin of small, medium and large cartons of smoked fish after insurgency

\begin{tabular}{llll}
\hline & $\begin{array}{l}\text { Present cost } \mathbf{( \mathbb { N } )} \\
\text { Small }\end{array}$ & Medium & Large \\
\hline Gross revenue & 13,500 & 34,733 & 69,333 \\
Purchasing price & 12000 & 33,335 & 65,333 \\
Rent & 121 & 250 & 900 \\
Transport & 25 & 50 & 72 \\
Loading/ offloading & 95.23 & 100.31 & 123.4 \\
Tax & 25.02 & 40.01 & 60.01 \\
Total variable & 12,266 & 20,440 & 66,488 \\
Gross margin & 1,733 & 1,389 & 2,844 \\
\hline
\end{tabular}

Source: Field Survey, 2016

The gross margin for smoked fish marketing was still positive even after the insurgency. This implies that the insurgency has impact on the profitability of the smoked fish marketing though total variable cost has increased after the insurgency. The marketing margin of the wholesalers and retailers indicates the risk incurred by the fish marketers (Jones, 1996). Although, this reveales that retailers had higher gross margin compared to wholesalers. This could be explained by the ability of wholesaler to handle bulk purchases for a long period of time. Transportation cost was found to constitute large portion of marketing margin in Africa (Abah, et al., 2013). 
Creative commons User License: CC BY-NC-ND

Abstracted by: EBSCOhost, Electronic Journals Service (EJS), Google Scholar, Directory of Open Access Journals (DOAJ), Journal Seek, Scientific Commons,

Food and Agricultural Organization (FAO), CABI and Scopus
Journal of Agricultural Extension

Vol. 21 (3) October, 2017

ISSN(e): 24086851; ISSN(Print); 1119944X

http://journal.aesonnigeria.org

http://www.ajol.info/index.php/jae

Email: editorinchief@aesonnigeria.org

\section{Conclusion and Recommendations}

In spite of the problems associated with fish marketing in Baga Park Fish Market Maiduguri, it is evident that fish marketing is profitable. The marketer stand to earn more profit if the problems associated with the business were taken care of, especially the recent case of insurgency. The study also indicates that dried smoked fish product was highly marketed and there was negative effect on the gross margin of the fish sellers.

Effort should be made to train the marketers, with the help of extension agents, on efficient fish processing and storage techniques. Attainment of such knowledge could help to reduce the level of losses and improve profit.

The local fish marketers should be organized into cooperatives. This could help members to improve their business through assistance such as loans and other benefits from the cooperative society.

The private sector in collaboration with the Nigerian government should adequately provide infrastructural facilities such as good roads; good market facilities and so on to reduce marketing cost of dried fish.

Government should make effort to standardize the unit of measurement for dried fish throughout the nation, so as to check the fraudulent activities in dried fish marketing

\section{References}

Abah, D., Zaknayiba, D. B. and E. Simon, E. (2013). Economic analysis of fish marketing in Lafia Local Government Area of Nasarawa State, Nigeria.

Production Agriculture Technology. 9.2: 54-62.

Abubakar, A. (2015). "Boko Haram launches deadly attack on northeastern Nigerian city". CNN. Retrieved 30 May 2015.

Adeleke, M. L. and Afolabi, J. A. (2012). Appraisal of fish marketing in Ondo State Nigeria. IIFET.

Aderolu, A. Z. and Akpabio, V. M. (2009). Growth and economic performance of Clarias gariepinus juveniles fed diets containing velvet bean, Mucuna pruriens, seed meal. African Journal of Aquatic Science. 34.2: 131-135.

Adeosun, O. and Adebukola, F. B. (2012). Determinants of income from fish marketing in Ibarapa Area of Oyo State, Nigeria. Science Journal of Agricultural Research \& Management. 135: 6.

Afolabi, J. A. (2008). Analysis of loan repayment among small scale farmers in south western Nigeria - A discriminant approach. Journal Social Sciences. 17.1: 83- 88.

Ahmed, M. E. (2008). Marketing of maize in Maiduguri Metropolitan Area of Borno State", B.sc project, Agricultural Economics and Extension Department, University of Maiduguri, Borno State.

Akinwumi, F.O. (2011). Evaluation of some plant materials for the control of smoked fish, Dermestes maculatus (Degeer) (Coleoptera:Dermestidae) in Clarias gariepinus Burchell (Pisces: Claridae). Journal of Agricultural and Biological science. 61: 7.

Akinwusi, F. (1995). Economics assesement and the marketing system of smoked fish in Ibadan and its environs, M.sc.Dissertation, University of Ibadan. Pp12- 32

Amusan, A. A. S. and Okorie, T.G. (2002). The use of Piper guineense fruit oil (PFO) as protectant of dried fish against Dermestes maculatus infestation. Global Journal of Pure and Applied Science.8: 197-201.

Ashamo, M. O. and Ajayi, O. E. (2003). Effect of processing and storage methods on the shelf life and incidence of insect pests on smoked fish. Global Journal of Pure and Applied Sciences. 9.3: 319-324. 
Creative commons User License: CC BY-NC-ND

Abstracted by: EBSCOhost, Electronic Journals Service (EJS), Google Scholar, Directory of Open Access Journals (DOAJ), Journal Seek, Scientific Commons,

Food and Agricultural Organization (FAO), CABI and Scopus

\section{Journal of Agricultural Extension}

Vol. 21 (3) October, 2017

ISSN(e): 24086851; ISSN(Print); 1119944X

http://journal.aesonnigeria.org

http://www.ajol.info/index.php/jae

Email: editorinchief@aesonnigeria.org

Azam, K., Ali, M. Y., Asaduzzaman, M., Basher, M. Z. and Hossain, M. M. 2004. Biochemical assessment of selected fresh fish. Journal of Biological sciences. 4.1: 910.

BOSADP (2007). Borno State Agricultural Development Programme (BOSADP) Office Memo File.

Faith, K. and Aminu, A. (2015)."Nigerian soldiers save one city from Boko Haram but a nearby one is seized". CNN.com. Retrieved 2015-01-29.

Fasakin E. A. and Aberejo B. A. (2002). Effect of smoked pulverized plant material on the developmental stages of fish beetles, Dermestes maculatus Degeer in smoked fish cat fish Clarias garienpinus during storage. Bioscience Technology. 85: 173-177.

Folorunso, A. A., Sambo, B. A., Danjuma, M., Usman, A., Ibeawuchi, R. K. and Edosa, O. (2006). Effect of insect infestation on nutritional quality of smoked fish species in Jos, Nigeria. Cameroon journal of experimental Biology. Vol. $\quad 2,01,26-30$.

Gona, A., Tanko, L. and Mohammed, I. (2004). Analysis of market performance of the food service industry in government area of Bayelsa State, Nigeria. World Journal of Young Researchers. 2: 1- 4.

Imoudu, P. B. and Afolabi, J. A. (2002). An Assessment of the Performance of Plantain Marketing in Ondo state. Inter Academy Council (IAC) (2004). Realizing the Promise and Potential of African Agriculture.

Johnson, C and Esser, J. (2005). A review of insect infestation of traditionally processed fish in the Tropics. Department for international development, London. 95pp.

Jones, S. (1996). Food markets in Developing Countries: what do we know? Food studies Group working paper No. 8 Oxford.

Kainga, P. E. and Adeyemo, A. O. (2012). Socio economic characteristics of fish marketers in Yenagoa Local Government Area of Bayelsa State, Nigeria. World Journal of Young Researchers. 2: 1- 4.

Kwaghe, P. V., Gaya, H. I. M. and Patrick, T. (2008). The economics of bush meat marketing in Maiduguri Metropolis of Borno State, Nigeria. Sahel Analyst. 1.1:21-28.

Lawal, W. L. and Idega, E. O. (2004). Analysis of fish marketing in Benue State. Proceedings of Annual Conference of the National Association of Agricultural Economists (NAAE).

Madugu, A. J. and Edward, A. (2011). Marketing and distribution channel of processed fish in Adamawa State, Nigeria. Global Journal of Management and Business Research. $11: 4$.

Ministry of Land and Survey (M. L. S., 2008), Borno State Office Memo File.

National Commission for Refuge Management (N.C.R.M) (2015), Abuja, Nigeria.

National Emergency Management Agency (N.E.M.A.( (2015), Abuja, Nigeria.

Nigerian Metrological Agency (N.M.A) (2008) Annual Report, Office Memo File Northeastern Nigeria. Journal Agriculture and Social Science 4:23-6

Nossifer, A. (2015). In Nigeria, New Boko Haram Suicide Bomber Tactic: It's a Little Girl. The New York Times. Retrieved 25 January 2015.

Ofuya, T. I. (2003). Beans, insects and man. Inaugural lecture series, Federal University of Technology, Akure. p.18.

Ogun State Agricultural Development Programme (OGADEP) (2005). Annual (in-House Review Fisheries Report. Ogun State Agricultural Development Programme (OGADEP) Fisheries Unit. Pp 10.

Ojo, S. O. and Fagbenro, O. A. (2004). Poverty reduction strategy in Nigeria- improving productivity and technical Efficiency in Artisanal Fisheries in Niger Delta Region. Bi- 
Creative commons User License: CC BY-NC-ND

Abstracted by: EBSCOhost, Electronic Journals Service (EJS),

Google Scholar, Directory of Open Access Journals (DOAJ),

Journal Seek, Scientific Commons,

Food and Agricultural Organization (FAO), CABI and Scopus

\section{Journal of Agricultural Extension}

Vol. 21 (3) October, 2017

ISSN(e): 24086851; ISSN(Print); 1119944X

http://journal.aesonnigeria.org

http://www.ajol.info/index.php/jae

Email: editorinchief@aesonnigeria.org

annual Conference of International Institute of Fisheries Economics and Trade (IIFET).

Okorie, U. (2003). Nigeria weeps. Owerri West: SNAAP Press Limited.

Olaoye, O. J., Adekoya, B. B., Ezeri, G. N. O., Omonyimi, G. A. K. and Ayansanwo, T. O. (2007). Fish hatchery production trends in Ogun state 2001-2006. Aquafield.3:29-40.

Olaoye, O. J. (2010): Dynamics of the Adoption Process of Improved Fisheries Technologies in Lagos and Ogun States Nigeria. A Ph. D thesis in the Department of Aquaculture and Fisheries Management, University of Agriculture, Abeokuta, Ogun State, Nigeria. Pp. 337.

Olukosi, J. O., Isitor, S. U. and Ode, M. O. (2005). Introduction to Agricultural Marketing and Prices: Principles and Applications, Living Books Series, G.U. Publications, Abuja, Nigeria.

Oloruntoba, A. and Adegbite, D. A. (2006). Improving agricultural extension services through university outreach initiatives: a case of farmers in model villages in Ogun State, Nigeria. Journal of agricultural education and extension. 12.4: 273-283.

Omamo, S. W. and Mose, L. O. (2001). Fertilizer trade under market liberalization: Preliminary evidence from Kenya. Food Policy. 26.1: 1-10.

Omoregie, E., Ofojekwu, P. C. and Dan-Kishiya, A. S. (2001). Effect of the pest, Dermestes maculatus (Degeer) (Coleoptera: Dermestidae) on dried Cyprinus muscle. Journal of Pest, Disease and Vector Management. 3: 423-451.

Orobiyi, R. A. (2007). "Economics of Dry Fish Marketing in Maiduguri Metropolitan Council" unpublished B.sc Thesis, Agricultural Economics and Extension Department, University of Maiduguri, Borno State.

Sabry, J. H. (1990). Nutritional aspects of fish consumption. A report prepared for the National Institute of Nutrition. Ottawa, Canada.

Tunaz, H. and Uygun, N. (2004). Insect Growth Regulators for Insect Pest Control. Turkish Journal Agriculture. 28: 377-387. 